\title{
Review \\ Design and Synthesis of Small Molecules as Potent Staphylococcus aureus Sortase A Inhibitors
}

\author{
Min Woo Ha ${ }^{1,2}$, Sung Wook $\mathrm{Yi}^{3}$ and Seung-Mann Paek ${ }^{4, *}$ \\ 1 College of Pharmacy, Jeju National University, 102, Jejudaehak-ro, Jeju, Jeju-do 63243, Korea; \\ minuha@jejunu.ac.kr \\ 2 Interdisciplinary Graduate Program in Advanced Convergence Technology \& Science, \\ Jeju National University, 102, Jejudaehak-ro, Jeju, Jeju-do 63243, Korea \\ 3 Department of Chemistry \& Biochemistry, University of California Los Angeles, CA 90095, USA; \\ woogie@chem.ucla.edu \\ 4 College of Pharmacy and Research Institute of Pharmaceutical Sciences, Gyeongsang National University, \\ Jinju Daero 501, Jinju, Gyeongsangnam-do 52828, Korea \\ * Correspondence: million@gnu.ac.kr; Tel.: +82-55-772-2424
}

Received: 28 August 2020; Accepted: 13 October 2020; Published: 16 October 2020

check for updates

\begin{abstract}
The widespread and uncontrollable emergence of antibiotic-resistant bacteria, especially methicillin-resistant Staphylococcus aureus, has promoted a wave of efforts to discover a new generation of antibiotics that prevent or treat bacterial infections neither as bactericides nor bacteriostats. Due to its crucial role in virulence and its nonessentiality in bacterial survival, sortase A has been considered as a great target for new antibiotics. Sortase A inhibitors have emerged as promising alternative antivirulence agents against bacteria. Herein, the structural and preparative aspects of some small synthetic organic compounds that block the pathogenic action of sortase A have been described.
\end{abstract}

Keywords: drug resistant; sortase A; Staphylococcus aureus; sortase A inhibitor; small organic molecule; synthetic chemistry

\section{Introduction}

Antibiotics are indispensable to the health of humankind [1-3]. Owing to the great contribution of commendable antibiotics, we might expect to extend our life expectancy over the age of 50 without substantial difficulties. Antibiotics deactivate bacterial infections by directly killing the bacteria and/or blocking its growth, ultimately preventing its spread [4]. However, the disconcerted emergence of antibiotic-resistant bacteria [5], which are resistant to several conventional antibiotics including $\beta$-lactam, cephalosporin, tetracycline, fluoroquinoline, macrolide, vancomycin, aminoglycoside, and trimethoprim-sulfamethoxazole, has become a serious social problem [6-9]. The greatest concerns regarding antibiotic-resistant bacteria, especially methicillin resistant Staphylococcus aureus (MRSA) for several difficult-to-treat infections in humans such as pneumonia, bacteremia, osteomyelitis, and endocarditis $[10,11]$, resulted in the development of a new generation of antibiotics that target the alternative enzyme components, fighting bacterial infections not as bactericides or bacteriostats $[12,13]$.

Since the elucidation of sortase, one of the membrane-bound cysteine transpeptidase in Gram-positive bacteria, in 1999, it has been regarded as a great target in the development of novel types of antibiotics. Its merits include: (1) its location on the extracellular membrane, (2) its lack of homologs in humans, and (3) its irrelevancy to bacterial growth [14,15]. Among the 1000+ homologs, sortase A in Staphylococcus aureus is known as the prototypical subtype [16,17]. To date, several research works have been published on the structure and mode of action of sortase A in S. aureus [18]. In terms of new drug design and discovery, a major achievement is associated with the development of sortase A inhibitors 
as anti-infective agents $[19,20]$. Sortase A inhibitors could be free from the consideration of their penetration inside the bacterial membrane. Sortase A inhibitors reduce the bacterial virulence caused by adhesion of the surface protein that carries disease-causing components to the host. Since sortase A is not required for the growth of $S$. aureus, drug resistance owing to sortase A inhibitors is less expected [21-35].

The enzymatic mode of action of sortase A commenced with the recognition step of the C-terminal amino acid sequence LPXTG (X means any amino acids) motif in the target surface protein. Sulfhydryl functionality of Cys184, one of the conserved residues in the catalytic domain, attacks nucleophilically the carbonyl carbon of Thr in the cell wall sorting signal, breaks down the Thr and Gly linkage, and affords the thioester intermediate. This covalent acyl-enzyme adduct undergoes another nucleophilic acyl substitution by the amino group of Gly in lipid II, forming the rigid amide bond; by virtue of these series of steps of sortase $\mathrm{A}$, the surface protein is incorporated into the peptidoglycan of the cell wall. Therefore, the most reliable strategy for inhibition of the enzyme is to inactivate the thiol functional group with a variety of electrophilic molecules covalently or non-covalently. Figure 1 displays the mechanism of sortase A (green) and its inactivation process through a sortase A inhibitor (yellow).

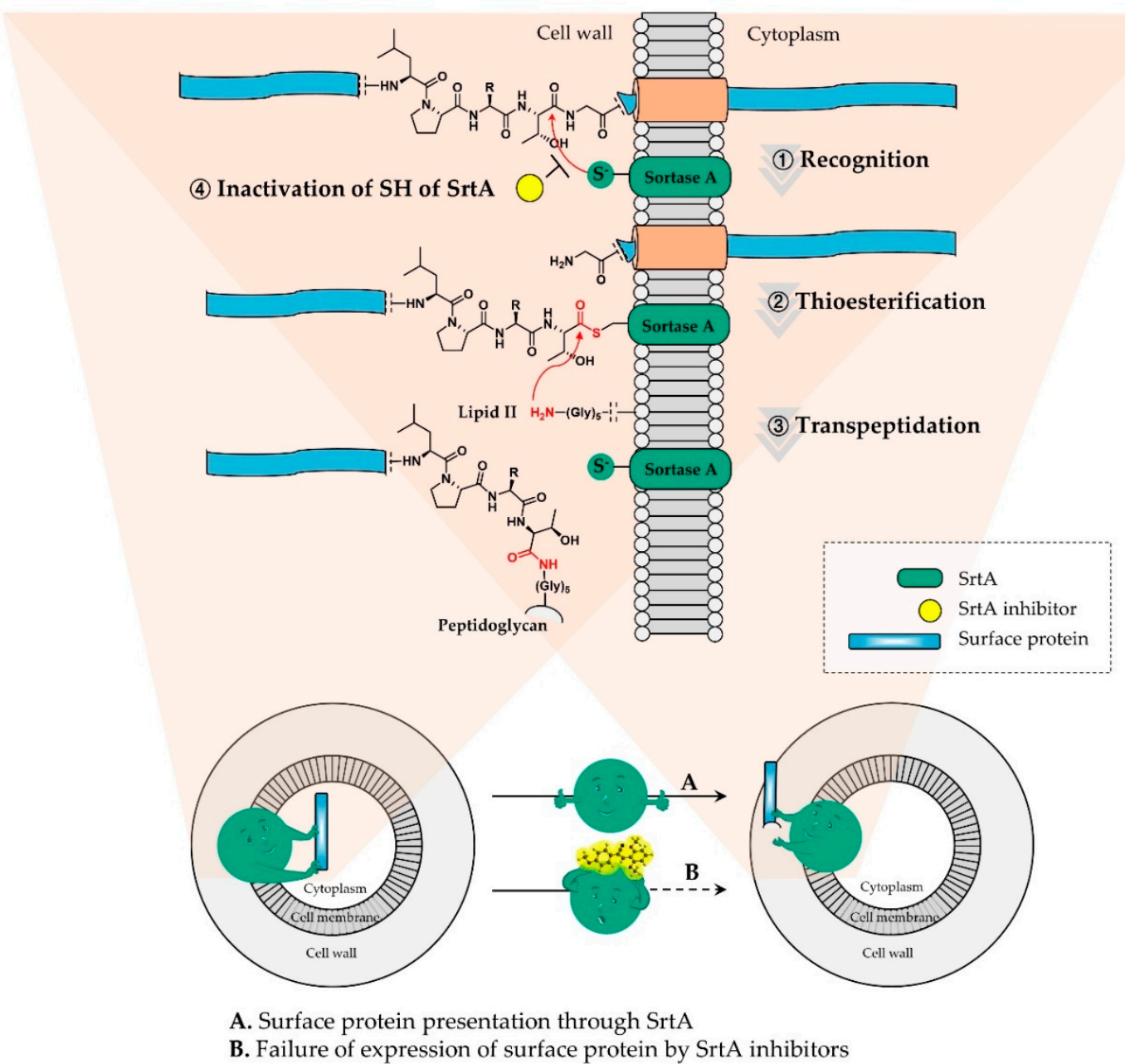

Figure 1. Mode of action of SrtA and its inactivation through its inhibitor; the surface proteins are covalently attached to the cell wall peptidoglycan with the aid of SrtA via the following sequential steps: (1) recognition, (2) thioesterification, and (3) transpeptidation. Further, they are inhibited for display, resulting in failure of adhesion to specific organ tissues, invasion of host cells, or the evasion of host-immune responses (4). 
With the attractive factors of sortase A, several strategies have been explored to isolate single ingredients with inhibitory activities against sortase A from natural products and compound libraries [36,37]. The design and synthesis of new molecules inspired by their own leading skeleton have also been discussed. Several synthetic small organic compounds constructively prepared by chemists were selected and described in this review. Further, a brief history of the molecular design and arrangement of a carbon skeleton is presented.

\section{Results and Discussion}

To explore the practicality of sortase A inhibitors, high-throughput screening (HTS) has been preliminarily adopted for constructive syntheses. In addition, further structural modifications through structure-activity relationship analysis have been performed to identify potential skeletons and functionalities. Several significant small organic molecules have been designed and synthesized, as shown in Figure 2, with promising $\mathrm{IC}_{50}$ values. Herein, the concrete synthetic features and the analytic properties for structural identification are described in the order of diarylacrylonitriles [38], pyridazinones [39], aryl 3-acryloamides [40], dihydro- $\beta$-carboline [41], benzisothiazolinones [42], triazolothiadiazoles [43], 2-(2-phenylhydrazinylidene)alkanoates [44], 2-phenyl-benzo[d] oxazole-7-carboxamide [45], 2-phenyl-benzofuran-7-carboxamide [46], 2-phenylthiazoles [47], 2, 5-disubstitued thiadiazole [48], and thiadiazolidinedione [49].

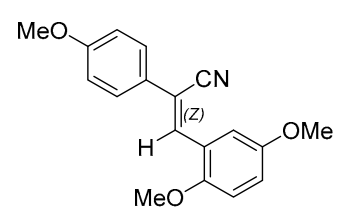

Diarylacrylonitrile $(9.2 \mu \mathrm{M}, \mathrm{Kim}, 2004)$

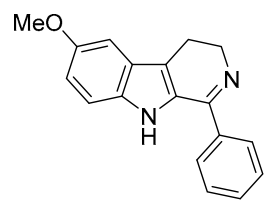

Dihydro- $\beta$-carboline $(25 \mu \mathrm{M}$, Oh \& Lee, 2010)

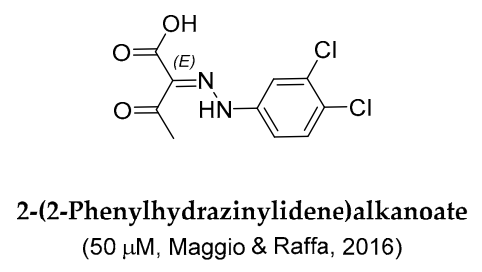

2-(2-Phenylhydrazinylidene)alkanoate (50 $\mu \mathrm{M}$, Maggio \& Raffa, 2016)

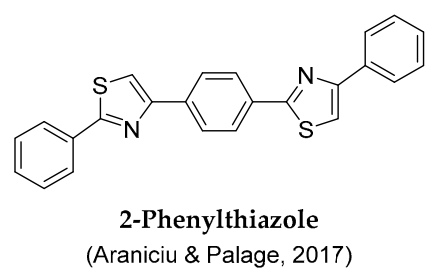

(Araniciu \& Palage, 2017)

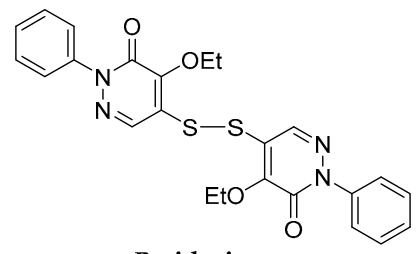

Pyridazinone

(1.5 $\mu \mathrm{M}$, Jung \& Clubb, 2009)

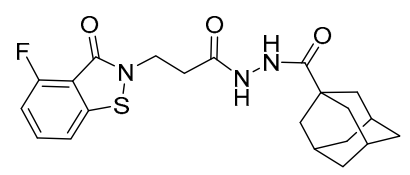

Benzoisothiazolinone (3.39 $\mu \mathrm{M}$, Zhulenkos, 2014)

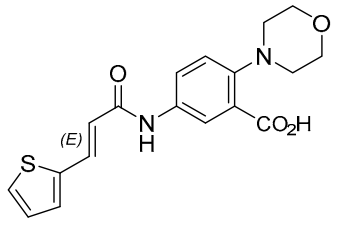

Aryl 3-acryloamide (75 $\mu \mathrm{M}$, Velu, 2010)

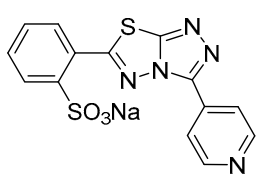

3,6-Disubstituted triazolothiadiazole (9.3 $\mu \mathrm{M}$, Schneewind \& Luo \& Yang, 2014)

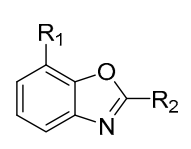

Benzo[d]oxazole (19.8 $\mu \mathrm{M}$, Jiang \& Fu, 2016)<smiles>[R]c1oc2ccccc2c1[R]</smiles>

Benzofuran (30.8 $\mu \mathrm{M}$, Jiang \& Fu, 2017)

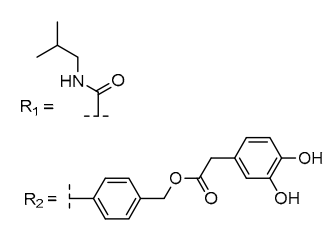

Figure 2. Synthetic small organic molecules as SrtA inhibitors ( $\mathrm{IC}_{50}$ values are given in parentheses). 


\subsection{Preparation of Diarylacrylonitriles}

Through random screening with the diverse small molecular library of 1000 compounds, a molecule of E-configurated diaryl acrylate was discovered with an $\mathrm{IC}_{50}$ of $231 \mu \mathrm{M}$ by the Kim research group [38]. With this attractive starting lead, a series of structural modifications such as E/Z-geometric isomerism, the absence of double bond, and substitution of ester for other functionalities was performed, which finally afforded Z-diarylacrylonitriles (5 and 9) with high inhibitory potencies against $S$. aureus. To prepare the two types of double bond structures, different synthetic strategies were used to obtain the corresponding isomer, as illustrated in Scheme 1 [50].
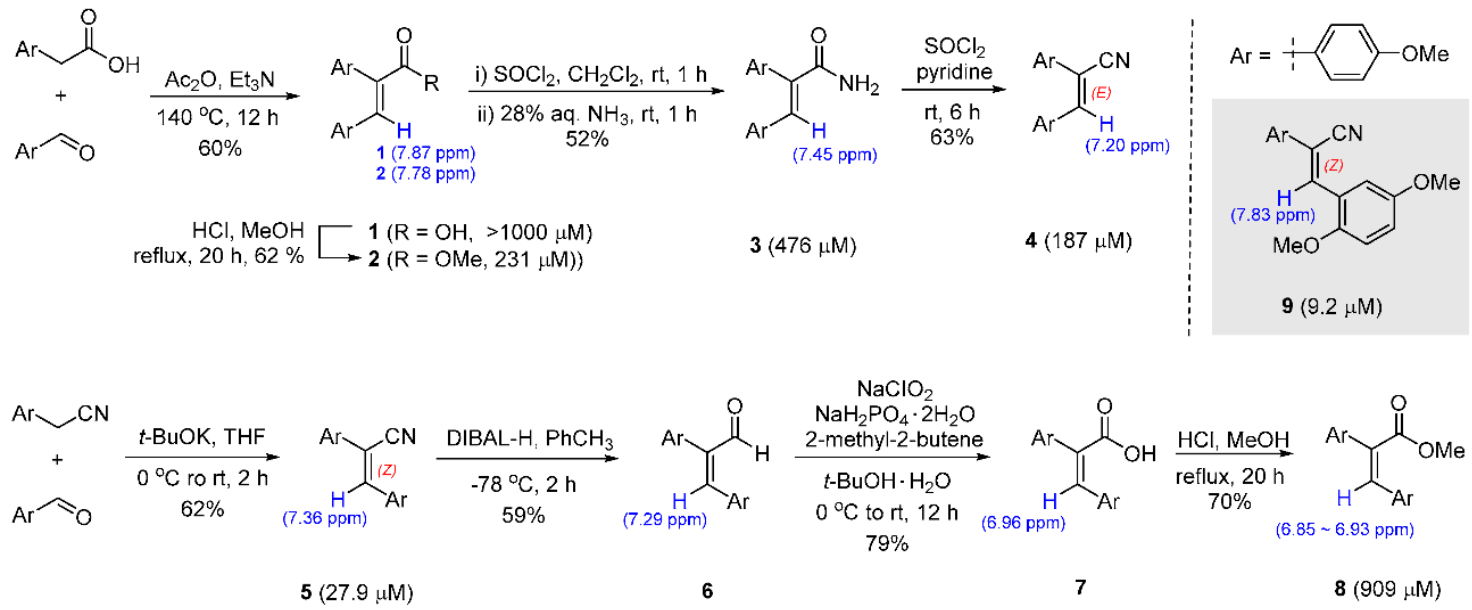

Scheme 1. Geometrically selective synthesis of diarylacrylonitriles ( $\mathrm{IC}_{50}$ values are given in parentheses).

The molecular geometry of the acrylic acid 1 condensed with $p$-methoxyphenyl acetic acid and $p$-anisaldehyde in acetic anhydride and trimethylamine was assigned the configuration $E$, while acrylonitrile 5, the adduct of $p$-methoxyphenyl acetonitrile and $p$-anisaldehyde under alkoxide basic condition, was synthesized with the entire Z-isomerism. Further chemical replacement via substitution, reduction, or oxidation was investigated and a few diarylacrylonitrile derivatives (2-8) were prepared. These simple and concise synthetic routes were adopted to obtain the best analog 9 with 2,5-dimethoxybenzaldehyde. The NMR spectroscopic analysis of olefinic hydrogen (colored in blue) is used to distinguish its E/Z geometry [51,52]; the hydrogen in the Z-configurated olefin appears to be slightly more upfield while the E-geometric hydrogen appears more downfield to the left. Even in this assignment, the comparison of $\mathbf{1}$ and 7, 2 and $\mathbf{8}$, and $\mathbf{4}$ and 5 revealed distinguishable information about the carbon skeletons [53].

\subsection{Preparation of Pyridazinones}

Three types of promising heterocycle ring skeletons, rhodanine, pyridazinone, and pyrazolethione, were introduced by the Jung and Clubb group to the HTS, with over 30,000 organic molecules having potential $\mathrm{IC}_{50}$ values of up to $3-5 \mu \mathrm{M}$ [39]. In particular, a further investigation of pyridazinone derivatives resulted in disulfide 15 , which had an $\mathrm{IC}_{50}$ value of $1.5 \mu \mathrm{M}$. Its potency was understood via thiol-disulfide exchange reaction with the $\mathrm{SH}$ residue of cysteine of sortase $\mathrm{A}$.

With a starting standard 10, the authors intended to investigate the influence of the position of the thiol moiety and proceeded to develop distinct synthetic methods for regioselective substitution with alkoxide to the $\alpha$ or $\beta$ position of unsaturated ketone. If the relatively mild reaction condition with $1 \mathrm{~N}$ of sodium hydroxide in ethanol proceeded with substrate 11, only $\beta$-substituted ethoxide was prepared. However, treatment with ethoxide anion generated in situ 1, 4-dioxane to 11, predominantly providing the $\alpha$-substituted counterpart. Moreover, the selective characteristics may depend on the length of the alkoxide carbon chain. Thus, their regioselectivities were determined through the nOe analysis between adjacent hydrogens in a molecule; these structural isomers showed their distinguishable 
identities on TLC analysis, as shown in Scheme 2. The remaining chlorine atoms of $\mathbf{1 2}$ and $\mathbf{1 4}$ were fairly quickly replaced with thiol 13 and 15 and thiol molecule 15 was oxidized to disulfide 16 in the presence of oxygen gas [54,55].

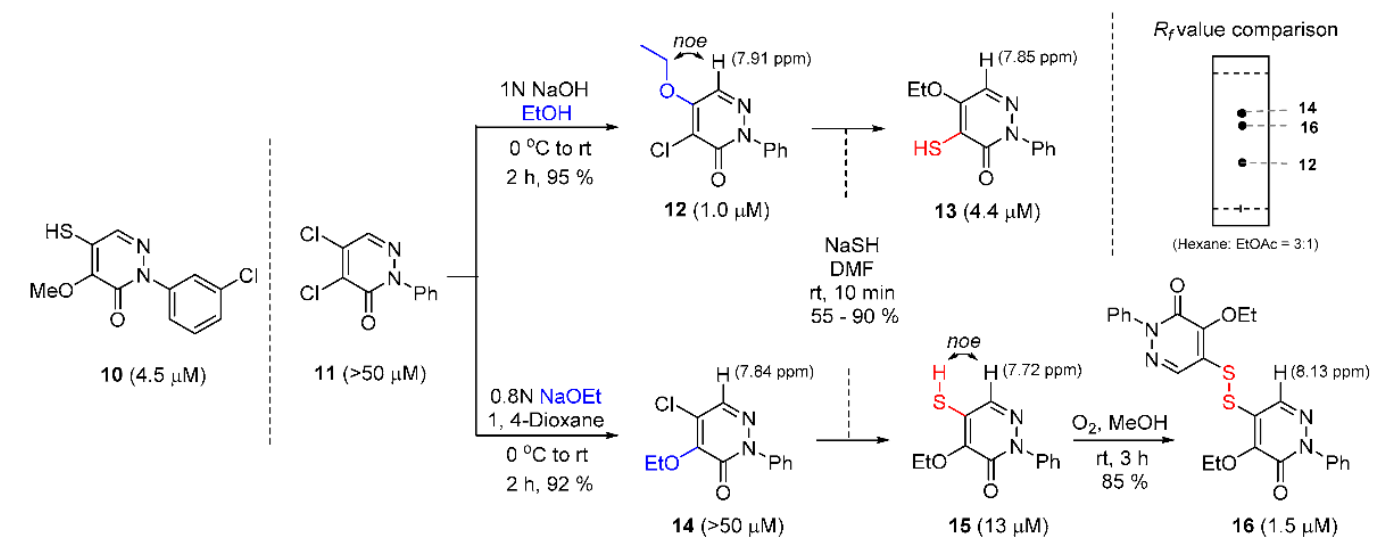

Scheme 2. Synthetic methods for pyridazinone derivatives via regioselective substitution $\left(\mathrm{IC}_{50}\right.$ values are given in parentheses).

\subsection{Preparation of Aryl 3-Acryloamide}

A series of synthetic molecules, presented as aryl 3-acryloamides, were prepared and their enzyme inhibiting actions were determined by the Velu research group [40]. The authors had performed systemic SAR studies that revealed the promising organic materials formed with the morpholinobenzoate group. To examine the effect of the geometry of the double bond on their activity, Z-configurated olefin molecules, 18 and 19, and E-configurated molecules, 20 and 21, were prepared using the optimized reaction methods presented in Scheme 3. As a result, the E stereochemistry was recognized to be more important than the $\mathrm{Z}$ configuration or rigid triple bond. Partial reduction with Lindlar catalyst, which is a well-established method for the synthesis of cis-olefin, did not provide the molecule 18, presumably due to the poisonous nature of the sulfur atom on the thiophene for palladium chemistry. However, the use of $\mathrm{H}_{2}$ gas in the presence of $\mathrm{Pd} / \mathrm{C}$ afforded the desired cis-alkene 18. For the synthesis of trans-isomer, the authors utilized the already-established cis-compound as the reactant [56,57].

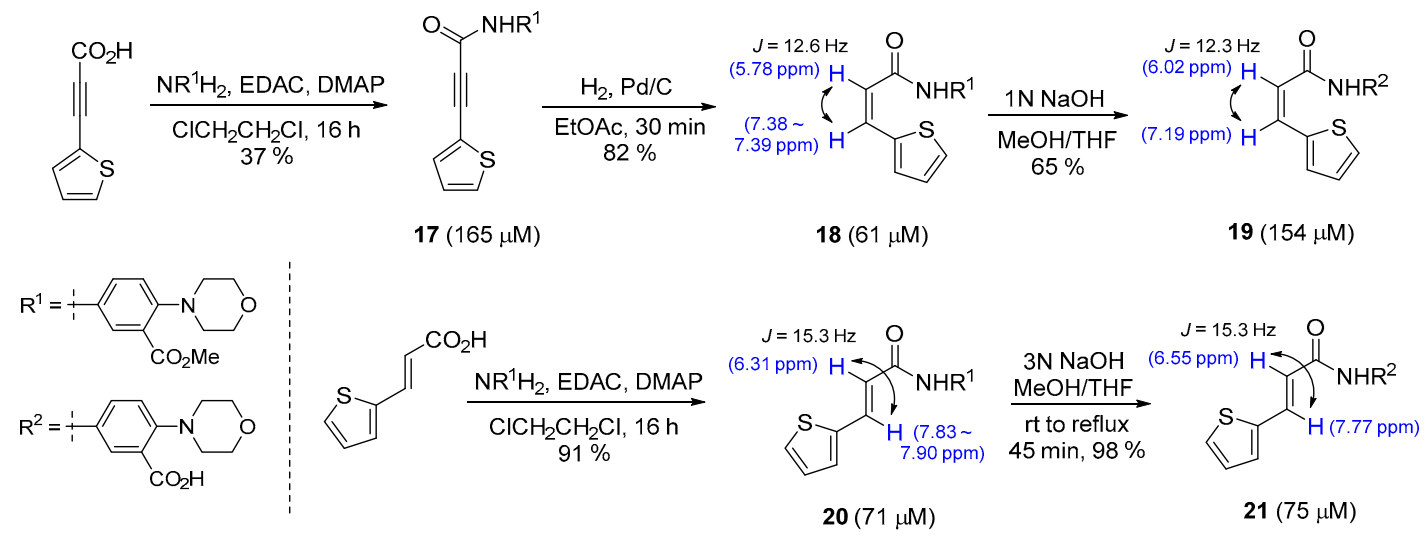

Scheme 3. Geometrically selective synthesis of aryl 3-acryloamides ( $\mathrm{IC}_{50}$ values are given in parentheses).

The stereochemistry of E/Z isomers can be elucidated through ${ }^{1} \mathrm{H}$ NMR analysis. On the ${ }^{1} \mathrm{H}$ NMR spectrum, the olefin hydrogens in 18 and 19 have shown different chemical shifts and coupling constants compared to those of $\mathbf{2 0}$ and $\mathbf{2 1}$. As expected, the apparent coupling constants were smaller 
in the cis-isomers than the trans-isomers. Further, it has been found that the olefinic hydrogens of the trans-diastereoisomer are located downfield than those of the cis-diastereoisomer to a certain degree.

\subsection{Preparation of Dihydro- $\beta$-Carboline}

A new heterocyclic skeleton, $\beta$-carboline, inspired by the structures of indole-containing natural products, was synthesized by the Oh and Lee group [41]. With 6-hydroxydihydro- $\beta$-carboline (22) as a standard and through a simple and fast synthetic route [58-61], the best inhibitor candidate 24 with an $\mathrm{IC}_{50}$ value of $25 \mu \mathrm{M}$ was observed. Briefly, condensation between 5-methoxy tryptamine and benzaldehyde followed by ring closure was very smoothly performed according to the Pictet-Spengler reaction, affording the tetrahydro- $\beta$-carboline 23 . Further, oxidation with the aid of the DDQ reagent resulted in the generation of dihydro- $\beta$-carboline $\mathbf{2 4}$ with good yield. As depicted in Scheme 4, replacement of carboxylic acid with a phenyl ring induced a marked increase in the inhibitory activity of sortase A.

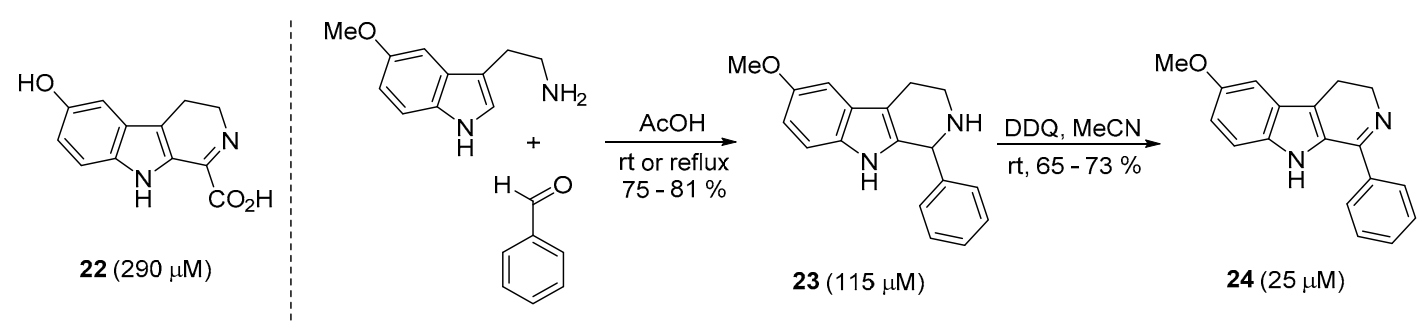

Scheme 4. Synthetic methods for tetrahydro- $\beta$-carboline and dihydro- $\beta$-carboline (IC 50 values are given in parentheses).

\subsection{Preparation of Benzoisothiazolinones}

From a small molecule library screening that included over 50,000 drug-like compounds, a new class of sortase A inhibitors, with $\mathbf{2 5}$ as a representative, was identified by the Zhulenkovs group [16]. The skeleton was comprised of benzo[d]isothiazol-3-(2H)-one heterocycle, which might form a covalent bond with the sortase A enzyme, the adamantyl moiety that offers the hydrophobic property, and an adequate linker. Owing to the results of the SAR analysis, the authors synthesized different combinations of the two ring moieties with 4-6 carboned spacers, which ultimately resulted in an $\mathrm{IC}_{50}$ value of $\sim 3 \mu \mathrm{M}$ (26). The core benzoisothiazolinone structure was prepared with the intermediate, 2-carbamoylbenzenesulfenyl bromide, via the treatment with bromine to disulfide. Additionally, the attachment of the adamantyl functionality was completed through evident EDC coupling (Scheme 5) [62-64].

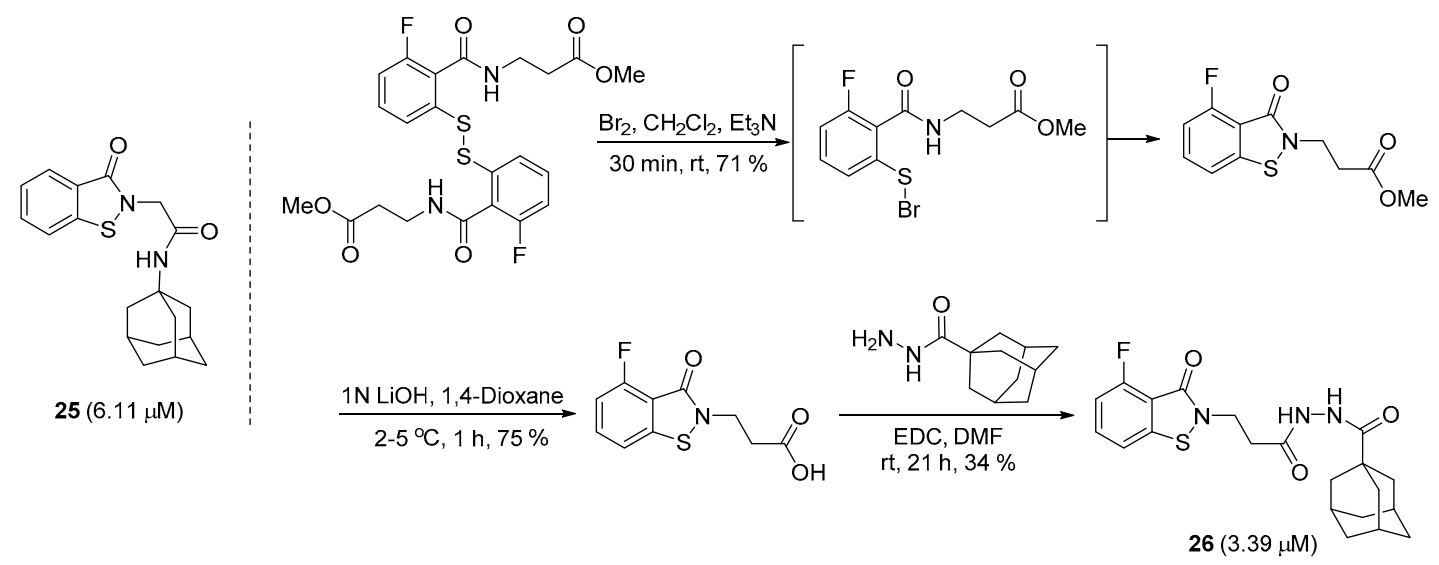

Scheme 5. Synthetic routes for benzisothiazolinone-based inhibitors $\left(\mathrm{IC}_{50}\right.$ values are given in parentheses). 


\subsection{Preparation of Triazolothiadiazoles}

After the acquisition of the hit compound 27 with a 3,6-disubstituted triazole structure, a synthetic optimization was performed by Schneewind, Luo, and Yang group [43], with few modifications, to discover the improved activity. The ethyl isonicotinate nucleophilic substitution with hydrazine was observed to occur as planned. Thereafter, isonicotinohydrazide was condensed with carbon disulfide in the presence of potassium hydroxide, producing potassium dithiocarbazate, and a triazole ring was formed upon treatment with hydrazine hydrate. Ultimately, the thiadiazole structure in $\mathbf{2 8}$ was achieved with 4-amino-5-aryl-3-mercapto-1,2,4-triazole and the corresponding benzoyl chloride in the presence of phosphorus oxychloride (Scheme 6) [65].

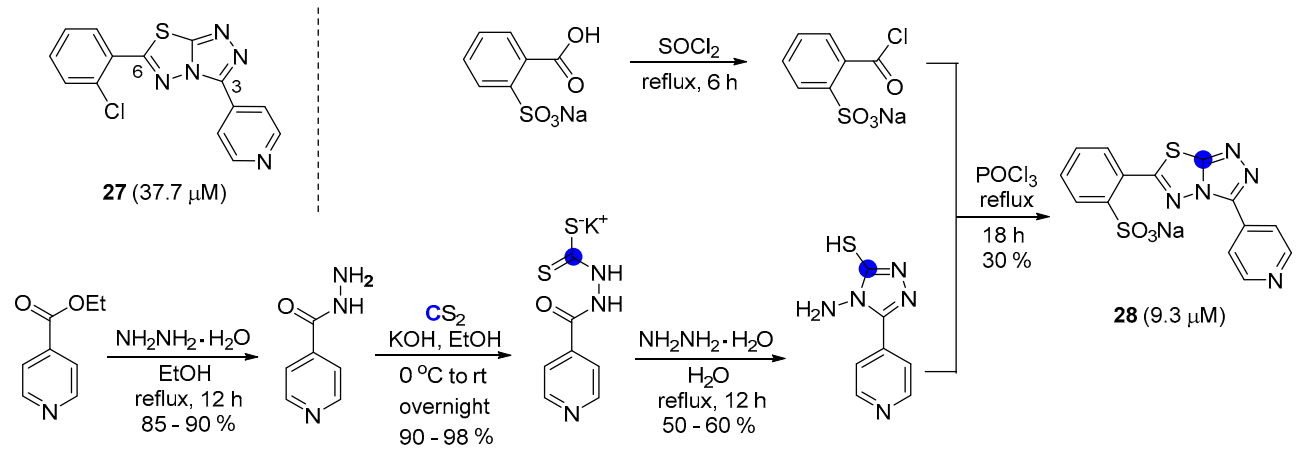

Scheme 6. Optimized synthetic scheme of the 3,6-disubstituted triazolothiadiazole scaffold ( $\mathrm{IC}_{50}$ values are given in parentheses).

\subsection{Preparation of 2-(2-Phenylhydrazinylidene)Alkanoates}

The Maggio and Raffa research group has studied the 1,3-dicarbonyl core skeleton with an aryl hydrazinylidene at the $\alpha$-position of $\beta$-keto ester as a novel class of sortase A inhibitors [44]. As shown in Scheme 7, the diazonium salt prepared from the substituted aniline was reacted with $\beta$-keto ester $\mathbf{2 9}$ or $\mathbf{3 0}[66,67]$. Thereafter, basic hydrolysis was carried out, affording the acids $\mathbf{3 3}$ and 34. During the synthesis of a series of analogs of the screened molecule, 35 , with an $\mathrm{IC}_{50}$ value of $192 \mu \mathrm{M}$, an issue ensued regarding the assignment of the geometry of the $\mathrm{C}=\mathrm{N}$ double bond for 31 and 32 [68-71]. Through a comparison of the ${ }^{1} \mathrm{H}$ NMR spectroscopic information for the reference molecules, the obtained materials, 31 and 32, were confirmed to be $\mathrm{E}$ and $\mathrm{Z}$, respectively [72-74]. For the E-configurated molecule, 31, the hydrogen of $\mathrm{NH}$ and the oxygen of the acetyl moiety form intramolecular hydrogen bonding, depicting an apparent downfield shift of $\mathrm{NH}$ and methyl signals compared to the Z-geometry $[75,76]$.

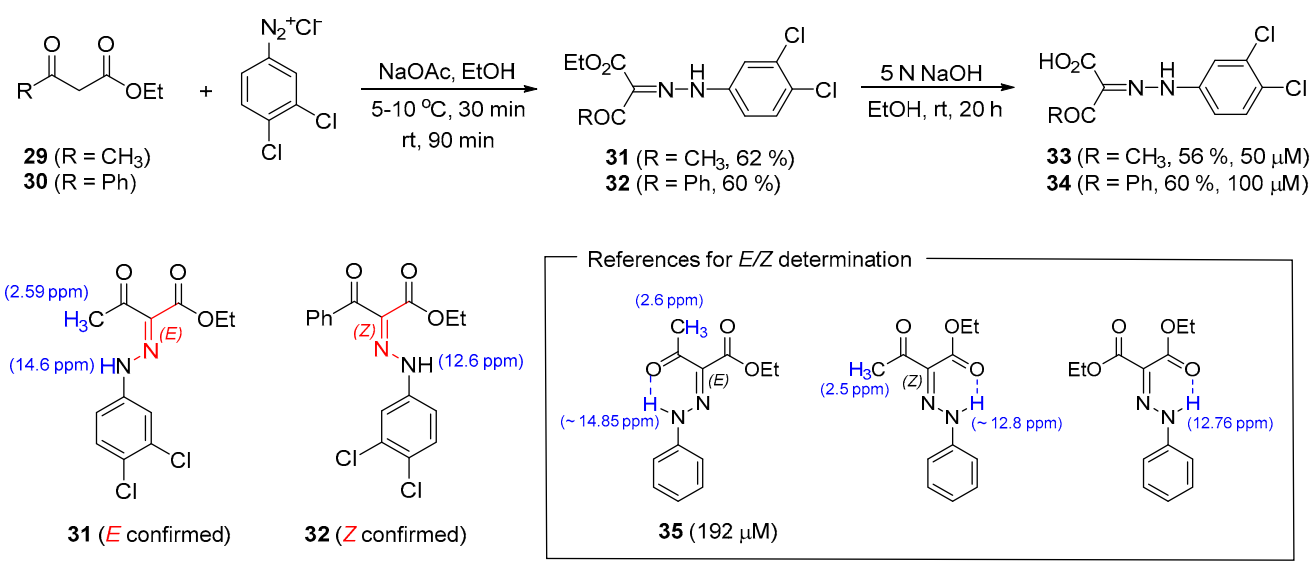

Scheme 7. Synthetic methods for 2-(2-phenylhydrazinylidene)alkanoates ( $\mathrm{IC}_{50}$ values of 33 and 34 are given in parentheses). 


\subsection{Preparation of Benzo[d]Oxazoles and Benzofuran}

During the search for a new frame of sortase A inhibitors, the Jiang and Fu research group developed L-shaped kinked molecules that mimic the sortase A substrate, LPXTG, sequentially designing 2-phenyl-benzo[d] oxazole-7-carboxamide and 2-phenyl-benzofuran-3-carboxamide [45,46]. Sortase A is known to recognize the LPXTG sorting signal (X means any amino acids) which is arranged in an L-shape mode by the L (Leu) and P (Pro) residues. The authors introduced an isobutyl amide functionality at the C-7 position of benzo[d] doxazoles and the C-3 position of benzofuran. Further, the core bicyclic rings were regarded as the displacement of pyrrolidine, and a right-side assembly of carbons and oxygens was expected to produce some spatial effect, mimicking the $\mathrm{X}$ amino acids in the substrate. The constructive methods of the objects are described in Scheme 8 [77].

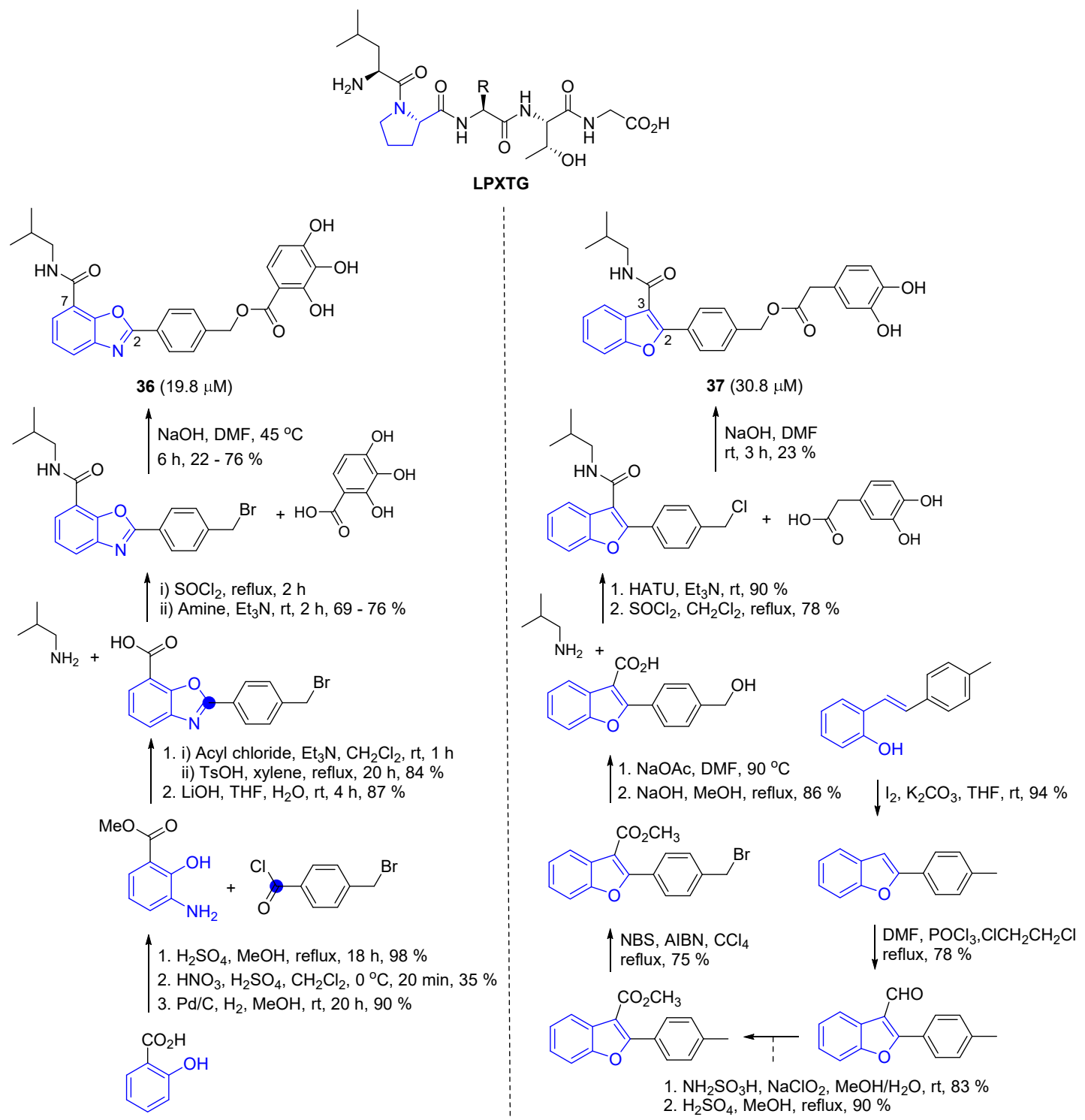

Scheme 8. Construction of the benzo[d]oxazole and benzofuran skeleton molecules $\left(\mathrm{IC}_{50}\right.$ values are given in parentheses).

In order to prepare the molecule 36, the authors used salicylic acid as a starting material. Following the protection of carboxylic acid to methyl ester of salicylic acid, a nitration reaction was carried out to introduce a nitryl group to an aryl ring [78]. Transformation of the nitryl functionality to amine under a hydrogen atmosphere in the presence of $\mathrm{Pd} / \mathrm{C}$ enabled the 2-hydroxyl aniline to react with 
4-methyl benzoyl bromide via intramolecular cyclization, resulting in benzoxazole. The deprotected free carboxylic acid derived via hydrolysis was then converted to acyl chloride. Thereafter, nucleophilic substitution with isobutyl amine was performed, followed by a final connection of the ester component via an undoubtful $\mathrm{S}_{\mathrm{N}} 2$ reaction [79].

To synthesize 2,3-substituted-benzofuran 37, (E)-2-(4-methylstyryl)phenol prepared via Wittig olefination was treated with iodine under basic conditions. Ring closure by iodination was then followed by a Vilsmeier reaction, resulting in a formyl moiety at the C-3 position. Following stepwise reactions, oxidation, esterification, bromination, hydrolysis, amide coupling, and substitution were performed.

\subsection{Preparation of Phenylthiazoles}

A study on the structural investigation of sortase A inhibitors through Bemis-Murcko scaffold analysis revealed that the scaffolds preferred for sortase A inhibitors contain at least two ring systems bonded directly or merged in a condensed cycle (Scheme 9). The Araniciu and Palage group designed a new framework of five aromatic rings linked directly and inspired by Bemis-Murcko clustering, ultimately synthesizing a series of 2-phenyl-thiazole derivatives 38 [47]. Briefly, thiobenzamide and 4-(2-bromoacetyl)benzonitrile were intramolecularly cyclized in one pot, affording the key intermediate, 4-(2-phenylthiazol-4-yl)benzonitrile. Treatment with hydrogen sulfide gas under triethylamine condition transformed nitrile into thioamide via a further thiazole ring formation reaction. Structures of the molecules were confirmed based on the distinct hydrogen signals on the ${ }^{1} \mathrm{H}$ NMR spectra and sharp signals between 3111 and $3103 \mathrm{~cm}^{-1}$ on the IR spectra [80]. Although the authors have not demonstrated the $\mathrm{IC}_{50}$ values of these sorts of new inhibitors, the antimicrobial activity evaluation showed that the potential scaffold has reduced activity against bacterial cell viability.
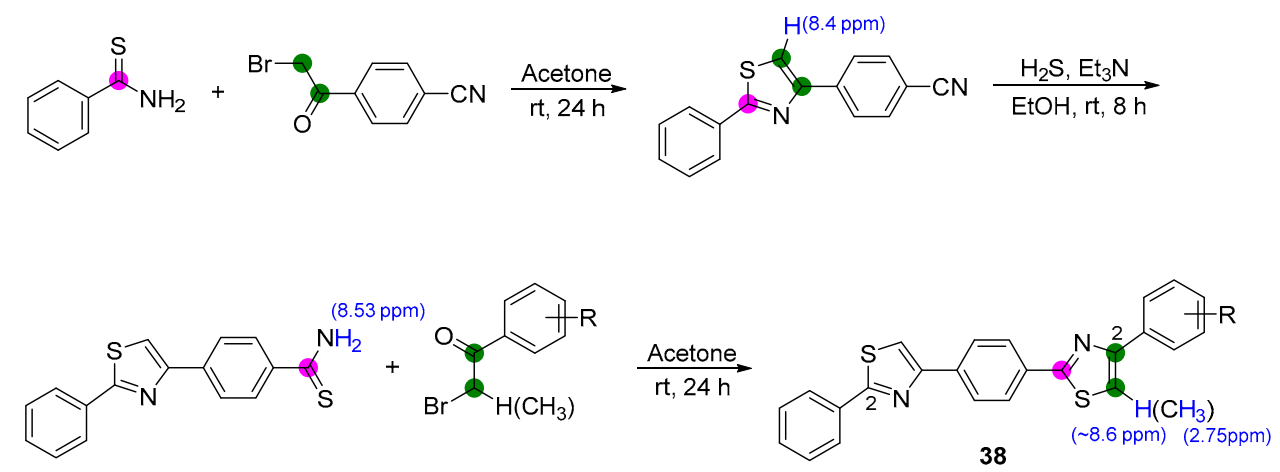

Scheme 9. Synthesis of 2-phenylthiazole derivatives within a pentacyclic system.

\subsection{Preparation of Thiadiazole}

The Olsson group identified a new class of inhibitors against S. aureus sortase A [48]. Through small-molecule libraries screening and PAINS (pan-assay interference compounds) study, top hit structures emerged. The hit compound $\mathbf{4 0}$ was selected as the starting point for structural hit-to-lead optimization. A series of modifications of $\mathbf{4 0}$ commenced with the removal of the oxadiazole unit which has been shown to cause cytotoxicity. Synthetic modifications included elongation of the sulfide substituent and addition of various substituted benzyl derivatives to validate some electronic effects. After all, N-(5-((4-nitrobenzyl)thio)-1,3,4-thiadiazol-2-yl)nicotinamide $\mathbf{4 1}\left(\mathrm{IC}_{50}=3.8 \mu \mathrm{M}\right)$ was identified as a potent inhibitor of sortase A. As illustrated in Scheme 10, 5-amino-1,3,4-thiadiazole-2-thiol was reacted with the appropriate bromide under basic conditions, affording the desired products in good yields. The primary amine was acylated, which was achieved upon treatment with nicotinoyl chloride 39 that was induced from nicotinic acid in situ [81-83]. 
<smiles>O=C(O)c1cccnc1</smiles>

39

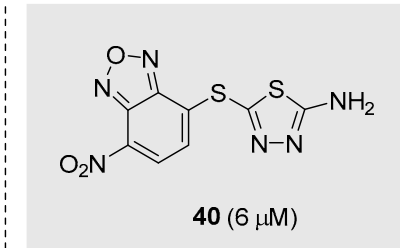

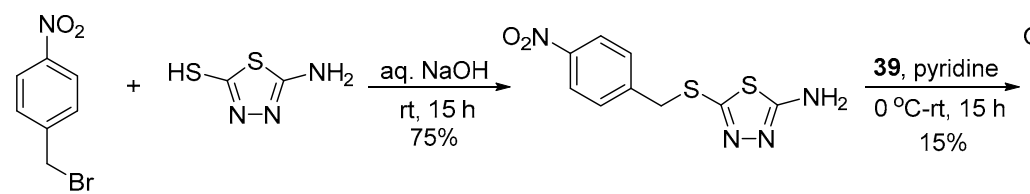<smiles>O=C(Nc1nnc(SCc2ccc([N+](=O)[O-])cc2)s1)c1cccnc1</smiles>

$41(3.8 \mu \mathrm{M})$

Scheme 10. Synthetic process for 2, 5-substituted thiadiazole ( $\mathrm{IC}_{50}$ values are given in parentheses).

\subsection{Preparation of Thiadiazolidinedione}

In an attempt to discover innovative scaffolds for sortase A inhibitors, the S. Yang and C.-G Yang research groups employed FRET-based HTS on a library consisting of over 2400 clinical drugs and candidates [49]. Tideglusib (TD), a drug candidate for myotonic dystrophy [84], was identified as a hit structure with an $\mathrm{IC}_{50}$ value of $5.9 \mu \mathrm{M}$. The authors prepared 40 sorts of TD analogs which were constructed with a thiadiazolidinedione skeleton and analyzed their structure-activity relationships for sortase A inhibition. Several molecules were explored, changing two N-substitutions with a variety of functionalities [85], and it was observed that the most promising compound, 42, bears 3,5-dimethylisoxazole substituent, retains inhibitory activities compared to that of TD, shows better solubility, and minimally inhibits the growth of the S. aureus. When it comes to the preparation of TD analogs, a concise synthetic route illustrated in Scheme 11 was adopted. The reaction system with an isothiocyanate, an isocyanate, and same equivalent molar amount of sulfuryl chloride $\left(\mathrm{SO}_{2} \mathrm{Cl}_{2}\right)$ even generated the unstable S-chloroisothiocarbamoyl chloride, and via the assembly with chloro-intermediates, the desired scaffold was established with good conversion efficiency.

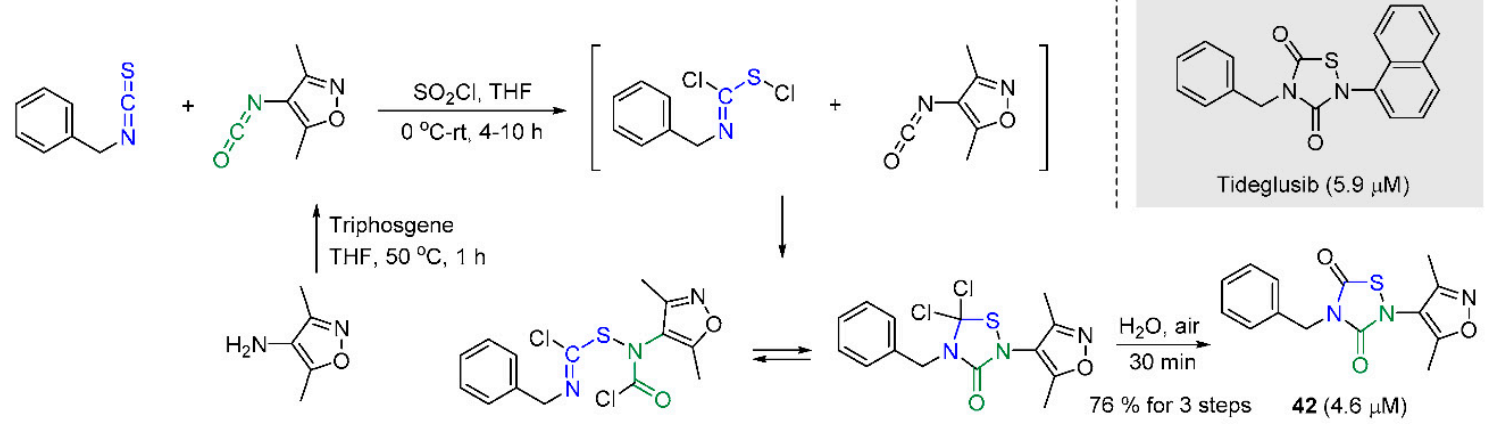

Scheme 11. Construction of the thiadiazolidinedione scaffold through chloro-intermediates $\left(\mathrm{IC}_{50}\right.$ values are given in parentheses).

\section{Conclusions}

Novel approaches for the development of antibiotics includes targeting virulence via toxin production and virulence factor secretion, impeding bacterial adhesion to host cells and biofilm formation, interrupting or inhibiting bacterial communication, and downregulating virulence. As part of the struggle against drug resistance, the development of sortase A inhibitor has emerged as an alternative to conventional antibiotics, with a mechanism that involves blocking the pathogenic processes of bacterial infection. The ideal inhibitors for sortase A should have minimal impacts on bacterial viability, which can be validated by their minimal inhibitory concentration (MIC) test. A number of influential advances in the development of sortase A inhibitors were comprehensively 
studied and reviewed by a variety research groups, but the interest and focus on their structural and preparative aspects are insufficient so far. It is of great interest to the medicinal chemists and associates how the core scaffolds are established and the tangent molecular groups are chemically installed. We the authors focus on the synthetic area and highlight significant small organic molecules with high inhibitory potencies against $\mathrm{S}$. aureus, eliciting the greatest $\mathrm{IC}_{50}$ values up to $1.5 \mu \mathrm{M}$.

The organic molecular group, aryl( $\beta$-amino)ethyl ketones, mainly abbreviated as AAEK and one of the promising S. aureus sortase A inhibitors, is known to their inhibitory mechanism [86]. In virtue of the kinetic analysis and mass spectrometry, it is suggested that the initial deprotonation of $\alpha$-position of AAEK by an appropriate base of sortase A facilitates the generation of an enolate which is stabilized by the guanidinium residue in the enzyme and then $\beta$-elimination, which means that the cleavage of the $\mathrm{C}-\mathrm{N}$ bond is undergone, releasing the separate moiety dimethylamine. Therefore, AAEK is now considered as an $\alpha, \beta$-unsaturated ketone at which 1,4-Michael type addition can be easily performed by the nucleophilic attack of the thiol group of cysteine in sortase A [87-90]. Through the irreversible covalent bond formation between sortase $\mathrm{A}$ and its inhibitor, the enzymatic action was attenuated. In a similar context, the $\alpha, \beta$-unsaturated carbonyl system of sortase A inhibitors is regarded as a Michael donor. Moreover, there are some sulfur containing sortase A inhibitors which inhibit sortase A by forming a disulfide bond with the cysteine residue, and it seems that most of the potent chemicals for sortase A bear sulfur (S) atoms in the molecules.

In summary, high-throughput screening and in silico virtual screening techniques from the small-molecule libraries have been widely used to discover novel types of scaffold sortase A inhibitors. As discussed above, we can determine the tendency that many compounds have $\alpha, \beta$-unsaturated carbonyl core or sulfur-associated functionalities. In the text, 12 sorts of skeletons, diarylacrylonitriles, pyridazinones, aryl 3-acryloamide, dihydro- $\beta$-carboline, benzisothiazolinones, triazolothiadiazoles, 2-(2-phenylhydrazinylidene)alkanoates, 2-phenyl-benzo[d]oxazole-7-carboxamide, 2-phenylbenzofuran-7-carboxamide, 2-phenylthiazoles, 2, 5-disubstitued thiadiazole, and thiadiazolidinedione, are demonstrated from a synthetic point of view. These cumulative achievements regarding sortase A inhibitors have provided the molecular basis for designing and synthesizing sortase A inhibitors. Their systematic development is thus expected to result in a novel class of antibiotics that would serve as antivirulence agents in the near future.

Author Contributions: M.W.H.: conceptualization, investigation and writing original draft. S.W.Y.: investigation and writing original draft. S.-M.P.: conceptualization, writing review and editing, and supervision. All authors have read and agreed to the published version of the manuscript.

Funding: This research was supported by the Korea Basic Science Institute (National Research Facilities and Equipment Center) through a grant funded by the Ministry of Education (grant No.: 2020R1A6C101A188). This research was funded by Basic Science Research Program to Research Institute for Basic Sciences (RIBS) of Jeju National University through the National Research Foundation of Korea (NRF) funded by the Ministry of Education. (2019R1A6A1A10072987).

Conflicts of Interest: The authors declare no conflict of interest.

\section{References}

1. Chaudhary, A.S. A review of global initiatives to fight antibiotic resistance and recent antibiotics' discovery. Acta Pharm. Sin. B 2016, 6, 552-556. [CrossRef]

2. Blair, J.M.; Webber, M.A.; Baylay, A.J.; Ogbolu, D.O.; Piddock, L.J. Molecular mechanisms of antibiotic resistance. Nat. Rev. Microbiol. 2015, 13, 42-51. [CrossRef]

3. Aslam, B.; Wang, W.; Arshad, M.I.; Khurshid, M.; Muzammil, S.; Rasool, M.H.; Nisar, N.A.; Alvi, R.F.; Aslam, M.A.; Qamar, M.U.; et al. Antibiotic resistance: A rundown of a global crisis. Infect. Drug. Resist. 2018, 11, 1645-1658. [CrossRef]

4. Kohanski, M.A.; Dwyer, D.J.; Hayete, B.; Lawrence, C.A.; Collins, J.J. A common mechanism of cellular death induced by bactericidal antibiotics. Cell 2007, 130, 797-810. [CrossRef]

5. DeLeo, F.R.; Chambers, H.F. Reemergence of antibiotic-resistant Staphylococcus aureus in the genomics era. J. Clin. Investig. 2009, 11, 2464-2474. [CrossRef] 
6. Chambers, H.J.; DeLeo, F.R. Waves of resistance: Staphylococcus aureus in the antibiotics. Nat. Rev. Microbiol. 2009, 7, 629-641. [CrossRef] [PubMed]

7. Neu, H.C. The crisis in antibiotic resistance. Science 1992, 257, 1064-1073. [CrossRef]

8. Baquero, F. Gram-positive resistance: Challenge for the development of new antibiotics. J. Antimicrob. Chemother. 1997, 39, 1-6. [CrossRef]

9. Andersson, H.; Lindholm, C.; Fossum, B. MRSA-global threat and personal disaster: patients' experiences. Int. Nurs. Rev. 2001, 58, 47-53. [CrossRef] [PubMed]

10. Grema, H.A.; Geidam, Y.A.; Gadzama, G.B.; Ameh, J.A.; Suleiman, A. Methicillin resistant Staphyloccus aureus (MRSA): A review. Adv. Anim. Vet. Sci. 2015, 3, 79-98. [CrossRef]

11. Kurosu, M.; Siricilla, S.; Mitachi, K. Advances in MRSA drug discovery: Where are we and where do we need to be? Expert Opin. Drug Discov. 2013, 8, 1095-1116. [CrossRef]

12. Wright, G.D.; Sutherland, A.D. New strategies for combating multidrug-resistant bacteria. Trends Mol. Med. 2007, 13, 260-267. [CrossRef]

13. Long, D.D.; Aggen, J.B.; Christensen, B.G.; Judice, J.K.; Hegde, S.S.; Kaniga, K.; Krause, K.M.; Linsell, M.S.; Moran, E.J.; Pace, J.L. A multivalent approach to drug discovery for novel antibiotics. J. Antibiot. Res. 2008, 61, 595-602. [CrossRef]

14. Ton-That, H.; Liu, G.; Mazmanian, S.K.; Faull, K.F.; Schneewind, O. Purification and characterization of sortase, the transpeptidase that cleaves surface proteins of Staphylococcus aureus at the LPXTG motif. Proc. Natl. Acad. Sci. USA 1999, 96, 12424-12429. [CrossRef]

15. Mazmanian, S.K.; Liu, G.; Ton-That, H.; Schneewind, O. Staphylococcus aureus sortase, an enzyme that anchors surface proteins to the cell wall. Science 1999, 285, 760-763. [CrossRef] [PubMed]

16. Ilangovan, U.; Ton-That, H.; Iwahara, J.; Schneewind, O.; Clubb, R.T. Structure of sortase, the transpeptidase that anchors proteins to the cell wall of Staphylococcus aureus. Proc. Natl. Acad. Sci. USA 2001, 98, 6056-6061. [CrossRef] [PubMed]

17. Frankel, B.A.; Kruger, R.G.; Robinson, D.E.; Kelleher, N.L.; McCafferty, D.G. Staphylococcus aureus sortase transpeptidase SrtA: Insight into the kinetic mechanism and evidence for a reverse protonation catalytic mechanism. Biochemistry 2005, 44, 11188-11200. [CrossRef]

18. Suree, N.; Liew, C.K.; Villareal, V.A.; Thieu, W.; Fadeev, E.A.; Clemens, J.J.; Jung, M.E.; Clubb, R.T. The structure of the Staphylococcus aureus sortase-substrate complex reveals how the universally conserved LPXTG sorting signal is recognized. J. Biol. Chem. 2009, 284, 24465-24477. [CrossRef] [PubMed]

19. Cascioferro, S.; Totsika, M.; Schillaci, D. Sortase A: An ideal target for anti-virulence drug development. Microb. Pathog. 2014, 77, 105-112. [CrossRef]

20. Maresso, A.W.; Schneewind, O. Sortase as a target of anti-infective therapy. Pharmacol. Rev. 2008, 60, $128-141$. [CrossRef]

21. Connolly, K.M.; Smith, B.M.; Pilpa, R.; Ilangovan, U.; Jung, M.E.; Clubb, R.T. Sortase from S. aureus does not contain a thiolate-imidazolium ion pair in its active site. J. Biol. Chem. 2003, 278, 34061-34065. [CrossRef]

22. Liew, C.K.; Smith, B.T.; Pilpa, R.; Ilangovan, U.; Connolly, K.M.; Jung, M.E.; Clubb, R.T. Localization and mutagenesis of the sorting signal binding site on sortase A from Staphylococcus aureus. FEBS Lett. 2004, 571, 221-226. [CrossRef] [PubMed]

23. Jung, M.E.; Clemens, J.J.; Suttee, N.; Liew, C.K.; Clubb, R.T. Synthesis of (2R,3S) 3-amino-4-mercapto-2-butanol, a threonine analogue for covalent inhibition of sortases. Bioorg. Med. Chem. Letts. 2005, 15, 5076-5079. [CrossRef] [PubMed]

24. Naik, M.T.; Suree, N.; Ilangovan, N.U.; Liew, C.K.; Clemens, J.; Jung, M.E.; Clubb, R.T. A calcium modulated loop closure mechanism activates cell surface protein anchoring by the Staphylococcus aureus sortase A transpeptidase. J. Biol. Chem. 2006, 281, 1817-182642. [CrossRef] [PubMed]

25. Ton-That, H.; Marraffini, L.A.; Schneewind, O. Protein sorting to the cell wall envelope of Gram-positive bacteria. Biochim. Biophys. Acta 2004, 1694, 269-278. [CrossRef] [PubMed]

26. Chan, A.H.; Wereszczynski, J.; Amer, B.R.; Yi, S.W.; Jung, M.E.; Clubb, R.T.; McCammon, J.A. Discovery of Staphylococcus aureus sortase A inhibitors using virtual screening and the relaxed complex scheme. Chem. Biol. Drug Des. 2013, 82, 418-428. [CrossRef]

27. Chan, A.H.; Yi, S.W.; Weiner, E.M.; Amer, B.R.; Sue, C.; Wereszczynski, J.; Dillen, C.; Senese, S.; Torres, J.Z.; McCammon, J.A.; et al. NMR structure-based optimization of Staphylococcus aureus sortase A pyridazinone inhibitors. Chem. Biol. Drug Des. 2017, 90, 327-344. [CrossRef] [PubMed] 
28. Zong, Y.; Bice, T.W.; Ton-That, H.; Schneewind, O.; Narayana, S.V. Crystal structures of Staphylococcus aureus sortase A and its substrate complex. J. Biol. Chem. 2004, 279, 31383-31389. [CrossRef]

29. Kruger, R.G.; Otvos, B.; Frankel, B.A.; Bentley, M.; Dostal, P.; McCafferty, D.G. Analysis of the substrate specificity of the Staphylococcus aureus sortase transpeptidase SrtA. Biochemistry 2004, 43, 1541-1551. [CrossRef]

30. Ton-That, H.; Mazmanian, S.K.; Faull, K.F.; Schneewind, O. Anchoring of surface proteins to the cell wall of Staphylococcus aureus sortase catalyzed in vitro transpeptidation reaction using LPXTG peptide and NH2-GLY3SUBSTRATES. J. Biol. Chem. 2000, 275, 9876-9881. [CrossRef]

31. Mazmanian, S.K.; Ton-That, H.; Schneewind, O. Sortase-catalysed anchoring of surface proteins to the cell wall of Staphylococcus aureus. Mol. Microbiol. 2001, 40, 1049-1057. [CrossRef] [PubMed]

32. Kruger, R.G.; Barkallah, S.; Frankel, B.A.; McCafferty, D.G. Inhibition of the Staphylococcus aureus sortase transpeptidase SrtA by phosphinic peptidomimetics. Bioorg. Med. Chem. 2004, 12, 3723-3729. [CrossRef] [PubMed]

33. Perry, A.M.; Ton-That, H.; Mazmanian, S.K.; Schneewind, O. Anchoring of surface proteins to the cell wall of Staphylococcus aureus III. Lipid II is an in vivo peptidoglycan substrate for sortase-catalyzed surface protein anchoring. J. Biol. Chem. 2002, 277, 16241-16248. [CrossRef] [PubMed]

34. Marraffini, L.A.; Ton-That, H.; Zong, Y.; Narayana, S.V.; Schneewind, O. Anchoring of surface proteins to the cell wall of Staphylococcus aureus a conserved arginine residue is required for efficient catalysis of sortase A. J. Biol. Chem. 2004, 279, 37763-37770. [CrossRef]

35. Kappel, K.; Wereszczynski, J.; Clubb, R.T.; McCammon, J.A. The binding mechanism, multiple binding modes, and allosteric regulation of Staphylococcus aureus Sortase A probed by molecular dynamics simulations. Protein Sci. 2012, 21, 1858-1871. [CrossRef]

36. Cascioferro, S.; Raffa, D.; Maggio, B.; Raimondi, M.V.; Schillaci, D.; Daidone, G. Sortase A inhibitors: Recent advances and future perspectives. J. Med. Chem. 2015, 58, 9108-9123. [CrossRef]

37. Guo, Y.; Cai, S.; Gu, G.; Guo, Z.; Long, Z. Recent progress in the development of sortase A inhibitors as novel anti-bacterial virulence agents. RSC Adv. 2015, 5, 49880-49889. [CrossRef]

38. Oh, K.-B.; Kim, S.-H.; Lee, J.; Cho, W.-J.; Lee, T.; Kim, S. Discovery of diarylacrylonitriles as a novel series of small molecule sortase A inhibitors. J. Med. Chem. 2004, 47, 2418-2421. [CrossRef]

39. Suree, N.; Yi, S.W.; Thieu, W.; Marohn, M.; Damoiseaux, R.; Chan, A.; Jung, M.E.; Clubb, R.T. Discovery and structure-activity relationship analysis of Staphylococcus aureus sortase A inhibitors. Bioorg. Med. Chem. 2009, 17, 7174-7185. [CrossRef]

40. Chenna, B.C.; King, J.R.; Shinkre, B.A.; Glover, A.L.; Lucius, A.L.; Velu, S.E. Synthesis and structure activity relationship studies of novel Staphylococcus aureus sortase A inhibitors. Eur. J. Med. Chem. 2010, 45, 3752-3761. [CrossRef]

41. Lee, Y.-J.; Han, Y.-R.; Park, W.; Nam, S.-H.; Oh, K.-B.; Lee, H.-S. Synthetic analogs of indole-containing natural products as inhibitors of sortase A and isocitrate lyase. Bioorg. Med. Chem. Lett. 2010, 20, 6882-6885. [CrossRef] [PubMed]

42. Zhulenkovs, D.; Rudevica, Z.; Jaudzems, K.; Turks, M.; Leonchiks, A. Discovery and structure-activity relationship studies of irreversible benzisothiazolinone-based inhibitors against Staphylococcus aureus sortase A transpeptidase. Bioorg. Med. Chem. 2014, 22, 5988-6003. [CrossRef] [PubMed]

43. Zhang, J.; Liu, H.; Zhu, K.; Gong, S.; Dramsi, S.; Wang, Y.-T.; Li, J.; Chen, F.; Zhang, R.; Zhou, L.; et al. Antiinfective therapy with a small molecule inhibitor of Staphylococcus aureus sortase. Proc. Natl. Acad. Sci. USA 2014, 111, 13517-13522. [CrossRef]

44. Maggio, B.; Raffa, D.; Raimondi, M.V.; Cascioferro, S.; Plescia, F.; Schillaci, D.; Cusimano, M.G.; Leonchiks, A.; Zhulenkovs, D.; Basile, L.; et al. Discovery of a new class of sortase A transpeptidase inhibitors to tackle Gram-positive pathogens: 2-(2-phenylhydrazinylidene)alkanoic acids and related derivatives. Molecules 2016, 21, 241. [CrossRef]

45. Zhang, Y.; Bao, J.; Deng, X.-X.; He, W.; Fan, J.-J.; Jiang, F.-Q.; Fu, L. Synthesis, biological evaluation and molecular docking of 2-phenyl-benzo[d]oxazole-7-carboxamide derivatives as potential Staphylococcus aureus Sortase A inhibitors. Bioorganic Med. Chem. Lett. 2016, 26, 4081-4085. [CrossRef]

46. He, W.; Zhang, Y.; Bao, J.; Deng, X.; Batara, J.; Casey, S.; Guo, Q.; Jiang, F.; Fu, L. Synthesis, biological evaluation and molecular docking analysis of 2-phenyl-benzofuran-3-carboxamide derivatives as potential inhibitors of Staphylococcus aureus Sortase A. Bioorg. Med. Chem. 2017, 25, 1341-1351. [CrossRef] 
47. Oniga, S.D.; Araniciu, C.; Palage, M.D.; Popa, M.; Chifiriuc, M.C.; Marc, G.; Pirnau, A.; Stoica, C.I.; Lagoudis, I.; Dragoumis, T.; et al. New 2-phenylthiazoles as potential sortase A inhibitors: Synthesis, biological evaluation and molecular docking. Molecules 2017, 22, 1827. [CrossRef] [PubMed]

48. Wehrli, P.M.; Uzelac, I.; Olsson, T.; Jacso, T.; Tietze, D.; Gottfries, J. Discovery and development of substituted thiadiazoles as inhibitors of Staphylococcus aureus sortase A. Bioorg. Med. Chem. 2019, 27, 115043-115053. [CrossRef] [PubMed]

49. Yang, T.; Zhang, T.; Guan, X.N.; Dong, Z.; Lan, L.; Yang, S.; Yang, C.G. Tideglusib and its analogues as inhibitors of Staphylococcus aureus SrtA. J. Med. Chem. 2020, 63, 8442-8457. [CrossRef] [PubMed]

50. Caldwell, H.C.; Craig, P.N.; Groves, W.G. Spasmolytics. III. 3-Tropanyl 2, 3-diarylacrylates. J. Med. Chem. 1970, 13, 1079-1081. [CrossRef]

51. Ohsumi, K.; Nakagawa, R.; Fukuda, Y.; Hatanaka, T.; Morinaga, Y.; Nihei, Y.; Ohishi, K.; Suga, Y.; Akiyama, Y.; Tsuji, T. Novel combretastatin analogues effective against murine solid tumors: Design and structure-activity relationships. J. Med. Chem. 1998, 41, 3022-3032. [CrossRef]

52. Meyers, M.J.; Sun, J.; Carlson, K.E.; Marriner, G.A.; Katzenellenbogen, B.S.; Katzenellenbogen, J.A. Estrogen receptor- $\beta$ potency-selective ligands: Structure-activity relationship studies of diarylpropionitriles and their acetylene and polar analogues. J. Med. Chem. 2001, 44, 4230-4251. [CrossRef]

53. Rummens, F.H.A.; De Haan, J.W. Spectroscopic studies on olefins-III: NMR of cis-and trans-disubstituted olefins. Org. Magn. Reson. 1970, 2, 351-355. [CrossRef]

54. Zhang, J.; Morton, H.E.; Ji, J. Confirmation and prevention of halogen exchange: Practical and highly efficient one-pot synthesis of dibromo-and dichloropyridazinones. Tetrahedron Lett. 2006, 47, 8733-8735. [CrossRef]

55. Lyga, J.W. The reaction of 2-substituted-4,5-dichloro-3(2H)-pyridazinones with alkoxides and alkylthiolates. Heterocycl. Chem. 1988, 25, 1757-1760. [CrossRef]

56. Skotnicki, J.S.; Kearney, R.M.; Smith, A.L. Synthesis of secorapamycin esters and amides. Tetrahedron Lett. 1994, 35, 197-200. [CrossRef]

57. Wadsworth, D.H.; Geer, S.M.; Detty, M.R. Preparation of arylpropiolate esters from trichlorocyclopropenium cation and elaboration of the esters to unsymmetrical 1, 4-pentadiyn-3-ones and unsymmetrical tellurapyranones. J. Org. Chem. 1987, 52, 3662-3668. [CrossRef]

58. Cox, E.D.; Cook, J. The Pictet-Spengler condensation: A new direction for an old reaction. Chem. Rev. 1995, 95, 1797-1842. [CrossRef]

59. Trujillo, J.I.; Meyers, M.J.; Anderson, D.R.; Hegde, S.; Mahoney, M.W.; Vernier, W.F.; Buchler, I.P.; Wu, K.W.; Yang, S.; Hartman, S.J.; et al. Novel tetrahydro- $\beta$-carboline-1-carboxylic acids as inhibitors of mitogen activated protein kinase-activated protein kinase 2 (MK-2). Bioorg. Med. Chem. Lett. 2007, 17, 4657-4663. [CrossRef]

60. Kawashima, Y.; Horiguchi, A.; Taguchi, M.; Tuyuki, Y.; Karasawa, Y.; Araki, H.; Hatayama, K. Synthesis and pharmacological evaluation of 1, 2, 3, 4-tetrahydro- $\beta$-carboline derivatives. Chem. Pharm. Bull. 1995, 43, 783-787. [CrossRef]

61. Shen, Y.-C.; Chen, C.-Y.; Hsieh, P.W.; Duh, C.-Y.; Lin, Y.-M.; Ko, C.-L. The preparation and evaluation of 1 -substituted 1, 2, 3, 4-tetrahydro-and 3, 4-dihydro- $\beta$-carboline derivatives as potential antitumor agents. Chem. Pharm. Bull. 2005, 53, 32-36. [CrossRef]

62. Sławik, T. Aminomethyl derivatives of (benzisothiazolin-3-one-2-yl) acetic acid amides and 2-(1, 2-benzisothiazoline-3-one-2-yl) propionic acid amides. Pharmazie 1991, 46, 777-780.

63. Lai, H.; Dou, D.; Aravapalli, S.; Teramoto, T.; Lushington, G.H.; Mwania, T.M.; Alliston, K.R.; Eichhorn, D.M.; Padmanabhan, R.; Groutas, W.C. Design, synthesis and characterization of novel 1, 2-benzisothiazol-3 $(2 \mathrm{H})$-one and 1, 3, 4-oxadiazole hybrid derivatives: Potent inhibitors of Dengue and West Nile virus NS2B/NS3 proteases. Bioorg. Med. Chem. 2013, 21, 102-113. [CrossRef] [PubMed]

64. Dou, D.; Alex, D.; Du, B.; Tiew, K.C.; Aravapalli, S.; Mandadapu, S.R.; Calderone, R.; Groutas, W.C. Antifungal activity of a series of 1, 2-benzisothiazol-3 (2H)-one derivatives. Bioorg. Med. Chem. 2011, 19, 5782-5787. [CrossRef] [PubMed]

65. Mathew, V.; Keshavayya, J.; Vaidya, V.P.; Giles, D. Studies on synthesis and pharmacological activities of 3 , 6-disubstituted-1, 2, 4-triazolo [3, 4-b]-1,3, 4-thiadiazoles and their dihydro analogues. Eur. J. Med. Chem. 2007, 42, 823-840. [CrossRef] [PubMed]

66. Elguero, J.; Jaequier, R.; Tarrago, J.G. Structure des produits de copulation du chlorurre de phényldiazonium avec les $\beta$-dicétones e les $\beta$-cétoesters. Bull. Soc. Chim. Fr. 1966, 2981-2989. 
67. Bose, A.K.; Kugajevsky, I. NMR spectral studies-IV: Some 15NH coupling constants. Tetrahedron 1967, 23, 1489-1497. [CrossRef]

68. Bandyopadhyay, P.; Guha, L.; Seenivasagan, T.; Sathe, M.; Sharma, P.; Parashar, B.D.; Kaushik, M.P. Synthesis and bio-evaluation of aryl hydrazono esters for oviposition responses in Aedes albopictus. Bioorg. Med. Chem. Lett. 2011, 21, 794-797. [CrossRef]

69. Ferguson, G.N.; Valant, C.; Horne, J.; Figler, H.; Flynn, B.L.; Linden, J.; Chalmers, D.K.; Sexton, P.M.; Christopoulos, A.; Scammells, P.J. 2-Aminothienopyridazines as novel adenosine A1 receptor allosteric modulators and antagonists. J. Med. Chem. 2008, 51, 6165-6172. [CrossRef]

70. Pareek, A.K.; Joseph, P.E.; Seth, D.S. A convenient route for the synthesis and spectral characterization of substituted pyrazolones. Orient. J. Chem. 2009, 25, 735-738.

71. Ballatore, C.; Brunden, K.; Crowe, A.; Huryn, D.; Lee, V.; Trojanowski, J.; Smith, A.; Huang, R.; Huang, W.; Johnson, R.; et al. Aminothienopyridazine Inhibitors of Tau Assembly. Patent WO2011037985 A8, 31 March 2011.

72. Gupta, S.C.; Mandal, D.K.; Rani, A.; Sahay, A.; Prasad, S.M. Ethyl 3-oxo-2-(2-phenyl-hydrazinylidene) butanoate: A re-determination. Acta Crystallogr. Sect. E Struct. Rep. 2011, 67, o470. [CrossRef] [PubMed]

73. Khudina, O.G.; Burgart, Y.V.; Shchegol'kov, E.V.; Saloutin, V.I.; Kazheva, O.N.; Chekhlov, A.N.; D'yachenko, O.A. Steric structure of alkyl 2-aryl(hetaryl)hydrazono-3-fluoroalkyl-3-oxopropionates. Russ. J. Org. Chem. 2009, 45, 801-809. [CrossRef]

74. Mitchell, A.; Nonhebel, D.C. Spectroscopic studies of tautomeric systems-III: 2-Arylhydrazones of 1,2,3-triketones. Tetrahedron 1979, 35, 2013-2019. [CrossRef]

75. Saez, R.; Otero, M.D.; Batanero, B.; Barba, F. Microwave reaction of diazonium salts with nitriles. J. Chem. Res. 2008, 2008, 492-494. [CrossRef]

76. Jirman, J.; Ly`cka, A. 13C-and 15N-NMR spectra of phenylazoacetoacetamides and similar compounds. Dyes Pigment. 1987, 8, 55-62. [CrossRef]

77. Yan, Y.; Qin, B.; Ren, C.L.; Chen, X.Y.; Yip, Y.K.; Ye, R.J.; Zhang, D.W.; Su, H.B.; Zeng, H.Q. Synthesis, structural investigations, hydrogen-deuterium exchange studies, and molecular modeling of conformationally stablilized aromatic oligoamides. J. Am. Chem. Soc. 2010, 132, 5869-5879. [CrossRef]

78. Janetzko, J.; Batey, R.A. Organoboron-based allylation approach to the total synthesis of the medium-ring dilactone (+)-antimycin A1b. J. Org. Chem. 2014, 79, 7415-7424. [CrossRef]

79. Reid, E.E. Esterification a review of the recent past and a look towards the future. Ind. Eng. Chem. 1937, 29, 1344-1350. [CrossRef]

80. Okamiya, J. The preparation and the rates of the reaction of heterocyclic (thiophen and thiazole) bromoketones with thioamides. Nippon Kagaku Zasshi 1966, 87, 594-600. [CrossRef]

81. Talath, S.; Gadad, A.K. Synthesis, antibacterial and antitubercular activities of some 7-[4-(5-amino-[1, 3, 4] thiadiazole-2-sulfonyl)-piperazin-1-yl] fluoroquinolonic derivatives. Eur. J. Med. Chem. 2006, 41, 918-924. [CrossRef]

82. Guan, P.; Hou, X.; Wang, F.; Yi, F.; Xu, W.; Fang, H. Design, synthesis and preliminary bioactivity studies of 1,3,4-thiadiazole hydroxamic acid derivatives as novel histone deacetylase inhibitors. Bioorgan. Med. Chem. 2012, 20, 3865-3872. [CrossRef] [PubMed]

83. Park, Y.T.; Jung, C.H.; Kim, K.W.; Kim, H.S. Synthesis of 2-pyridinylbenzoxazole: Mechanism for the intramolecular photosubstitution of the haloarene with the carbonyl oxygen of the amide bond in basic medium. J. Org. Chem. 1999, 64, 8546-8556. [CrossRef]

84. Study of tideglusib in adolescent and adult patients with myotonic dystrophy (NCT02858908). ClinicalTrials. 2016. Available online: https://clinicaltrials.gov/ct2/show/NCT02858908 (accessed on 3 September 2020).

85. Turner, E.M.; Blazer, L.L.; Neubig, R.R.; Husbands, S.M. Small molecule inhibitors of regulator of G protein signalling (RGS) proteins. ACS Med. Chem. Lett. 2012, 3, 146-150. [CrossRef] [PubMed]

86. Maresso, A.W.; Wu, R.; Kern, J.W.; Zhang, R.; Janik, D.; Missiakas, D.M.; Duban, M.-E.; Joachimiak, A.; Schneewind, O. Activation of inhibitors by sortase triggers irreversible modification of the active site. J. Biol. Chem. 2007, 282, 23129-23139. [CrossRef]

87. Naidu, B.N.; Sorenson, M.E.; Connolly, T.P.; Ueda, Y. Michael addition of amines and thiols to dehydroalanine amides: A remarkable rate acceleration in water. J. Org. Chem. 2003, 68, 10098-10102. [CrossRef] 
88. Davioud-Charvet, E.; McLeish, M.J.; Veine, D.M.; Giegel, D.; Arscott, L.D.; Andricopulo, A.D.; Becker, K.; Muller, S.; Schirmer, R.H.; Williams, C.H., Jr.; et al. Mechanism-based inactivation of thioredoxin reductase from Plasmodium falciparum by Mannich bases. Implication for cytotoxicity. Biochemistry 2003, 42, 13319-13330. [CrossRef]

89. Mollica, J.A.; Smith, J.B.; Nunes, I.M.; Govan, H.K. Kinetics of the decomposition of a Mannich base. J. Pharm. Sci. 1970, 59, 1770-1774. [CrossRef]

90. Andrisano, R.; Angeloni, A.S.; De Maria, P.; Tramontini, M. Reactivity of mannich bases. Part X. The mechanism of the reaction between $\beta$-amino-ketones and thiophenols. J. Chem. Soc. C 1967, 43, 2307-2311. [CrossRef]

Publisher's Note: MDPI stays neutral with regard to jurisdictional claims in published maps and institutional affiliations.

(C) 2020 by the authors. Licensee MDPI, Basel, Switzerland. This article is an open access article distributed under the terms and conditions of the Creative Commons Attribution (CC BY) license (http://creativecommons.org/licenses/by/4.0/). 